\title{
UV-radiation effects on photosynthesis, photosynthetic pigments and $U V$-absorbing substances in three species of tropical lotic macroalgae
}

\author{
Anna Isabel N. Bautista-Saraiva · José Bonomi-Barufi · Félix L. Figueroa • \\ Orlando Necchi Jr.
}

Received: 23 April 2018/Accepted: 29 June 2018/Published online: 7 August 2018

(C) Brazilian Society of Plant Physiology 2018

\begin{abstract}
Freshwater algae inhabiting shallow waters are most effectively affected by UV radiation. The aim of this study was to analyze the photosynthetic performance (parameters derived of chlorophyll fluorescence), chlorophyll $a$ concentrations and the content of UV-absorbing compounds (mycosporinelike aminoacids-MAAs) in three tropical lotic macroalgae, Cladophora glomerata (Chlorophyta), Spirogyra sp. (Streptophyta) and Sirodotia delicatula (Rhodophyta) in response to UV radiation exposure under laboratory conditions. Experiments were performed under three treatments: (1) PAR (400-700 nm), P; (2) PAR + UVA (320-700 nm),
\end{abstract}

Electronic supplementary material The online version of this article (https://doi.org/10.1007/s40626-018-0113-6) contains supplementary material, which is available to authorized users.

A. I. N. Bautista-Saraiva

Federal Institute of Education, Science and Technology of São Paulo (IFSP), Campus of Votuporanga, Av. Jerônimo Figueira da Costa, 3014, Votuporanga, SP 15503-110, Brazil

J. Bonomi-Barufi

Botany Department, Federal University of Santa Catarina, Campus Trindade, s/n. CEP, Florianópolis,

SC 88040-900, Brazil

F. L. Figueroa

Ecology Department, Sciences Faculty, Málaga

University, Campus of Teatinos, 29071 Malaga, Spain
PA; (3) PAR + UVA + UVB (280-700 nm), PAB. Cladophora glomerata and Spirogyra sp., typical sunadapted lotic macroalgae, had distinct responses to UV radiation exposure. A more pronounced decrease of $F_{\mathrm{v}} / F_{\mathrm{m}}$ and increase of $N P Q$ under UVA than UVAB was observed, whereas chlorophyll $a$ content was lower under UVAB in C. glomerata. Spirogyra sp. had a decrease of photosynthetic yields $\left(\Delta F / F_{\mathrm{m}}{ }^{\prime}\right.$ and $F_{\mathrm{v}} /$ $\left.F_{\mathrm{m}}\right)$ under PAR, indicating that UVAB radiation may have a positive effect on the photosynthetic apparatus. Surprisingly, S. delicatula, a shade-adapted alga, exhibited less sensitivity to UV exposure. These results suggest that the presence of MAAs (shinorine and palythine) in S. delicatula is a significant shield of protection against UV radiation.

O. Necchi Jr. ( $₫)$

Zoology and Botany Departament, São Paulo State

University, Rua Cristóvão Colombo, 2265,

S. José Rio Preto, SP 15054-000, Brazil

e-mail: orlando@ibilce.unesp.br 
Keywords Chlorophyll fluorescence - Green algae · Photosynthesis · Red algae $\cdot$ Radiation $\cdot \mathrm{UV}$-absorbing substances

\section{Introduction}

It is widely reported that climate changes, caused mainly by increase in greenhouse gas concentrations, have strong interactions with ozone depletion, causing important consequences for UV exposure in aquatic ecosystems (Häder et al. 2015). As a consequence, this scenario emphasizes the need for studies on effects of UV radiation on biological systems (Rastogi et al. 2014).

Photosynthesis is one of the main metabolic functions of algae, and it is responsible for transfering energy for their maintenance and growth (Sabater et al. 2016), and among various physiological processes, it is potentially the main target of UV irradiation, not only in flowering plants, but also in algae (Häder and Figueroa 1997). Damage in D1 protein of photosystem II or in the Rubisco enzyme, decrease of photosynthetic pigments and reduced expression of genes involved in photosynthesis are the main mechanisms responsible for the decrease in photosynthetic activity after UV treatment (Holzinger and Lütz 2006). However, UV radiation does not always have a deleterious effect on aquatic photosynthetic organisms. Positive effects of UVB radiation were observed in the green alga Zygnemopsis decussata growing in a high mountain lake (Figueroa et al. 2009) and in tropical marine macroalgae (Hanelt and Roleda 2009), while positive effects of moderate levels of UVA radiation on photosynthesis and growth were reported for the red alga Gracilaria vermiculophylla (Roleda et al. 2012).

UV susceptibility was determined to be most pronounced in deep-water species and reduced in shallow-water species (Peschek et al. 2010). To deal with extreme variations in PAR (photosynthetically active radiation) and UV radiation, macroalgae in shallow environments have set different physiological acclimation mechanisms, that are important in determining variations in photosynthetic responses (Häder and Figueroa 1997; Hanelt and Figueroa 2012). Likewise, Germ (2005) observed that the capability for acclimation of photosynthesis to changing radiation environments is an important prerequisite for macroalgae, especially in areas with high natural radiations.

Benthic algae communities are the most successful primary producers exploiting habitats, and they are the main source of energy for higher trophic levels in many lotic ecosystems (Stevenson 1996). Among benthic algae, macroalgae is an important component of the communities in rivers and streams, with green algae tending to predominate (35-37\% of species) in floras of well-studied regions of the world, whereas contributions of other algal groups varying considerably (Necchi 2016): cyanobacteria (24-35\%), red algae (14-20\%), diatoms, and yellow-green algae (14-21\%). Among the green algae, filamentous forms are very common in lotic habitats, with some genera reported in several regions of the world (e.g., Cladophora and Spirogyra), whereas freshwater red algae occur almost exclusively in streams and rivers with members of the order Batrachospermales being widespread.

Spirogyra is an unbranched filamentous green alga that forms free-floating mats in shallow freshwaters (Graham et al. 1995). A previous study reported that Spirogyra can not maintain optimal rates of photosynthesis at high temperatures and low light, but can tolerate cool water and high irradiances (Graham et al. 1995), while Necchi (2004) reported Spirogyra sp. as a typical sun-adapted lotic macroalgae. Germ (2005) have reported the effects of UV radiation (specifically UVB) on Spirogyra sp. and concluded that this alga have physiological plasticity and resistance under enhanced UVB radiation.

Cladophora glomerata (L.) Kützing 1843 is one of the most widespread freshwater macroalgal species in the world (Dodds and Gudder 1992) and can be found almost throughout the year in shaded or open sites (Ensminger et al. 2000). Many aspects of the ecophysiology of $C$. glomerata have been summarized by Ensminger et al. (2000), Necchi et al. (2004), and Bautista and Necchi (2008) as a macroalga either shade or sun-adapted and could be classified as a stress-tolerant species regarding to temperature and light. The only specific study about photosynthetic performance under UV radiation was conducted by Choo et al. (2005), who studied different stress conditions in two green macroalgae and have reported that photosynthesis in C. glomerata was inhibited by UVB radiation. 
Freshwater red algae have been indicated as shadeadapted in previous studies (Necchi and Zucchi 2001; Necchi 2004, 2005), although some species can tolerate high irradiances. Photosynthetic characteristics of Sirodotia delicatula Skuja (treated as Batrachospermum delicatulum) exhibited a wide range of responses to irradiance (Necchi and Alves 2005), suggesting they have mechanisms that enable them to avoid photodamage of the photosynthetic apparatus (Necchi 2005). While several studies reported harmful UV radiation effects, especially UVB (Figueroa et al. 1997; Roleda et al. 2004; Simioni et al. 2014), there are only few studies dealing with the responses to UV radiation in freshwater red algae (Arróniz-Crespo et al. 2005; Aigner et al. 2017; Bautista-Saraiva et al. 2017). Arróniz-Crespo et al. (2005) found two MAAs (Porphyra-334 and mycosporine-glycine) induced by UV radiation in Lemanea fluviatilis (Linnaeus) C. Agardh, the former being specifically induced by UVB radiation, whereas the latter was degraded by this radiation. They also observed damages in the alga as reductions in photosynthetic activity and photosynthetic pigments. Aigner et al. (2017) reported that exposure to either UVA or UVAB led to a strong transient drop in effective quantum yield in Batrachospermum turfosum Bory, but the alga was capable of recovering it after being removed from the UVR treatment. Bautista-Saraiva et al. (2017) found one type of MAA (shinorine or Porphyra-334) in gametophyte under UVA and UVB in culture conditions, but not in the 'Chantransia' stage of Kumanoa ambigua (Montagne) Entwisle, Vis, Chiasson, Necchi et Sherwood. The increased photosynthetic performance and the presence of MAA in gametophyte suggested that it is less sensitive to UV radiation, particularly UVA, in comparison to sporophyte.

The aim of this study was to analyze the photosynthetic performance (parameters estimated by chlorophyll fluorescence), chlorophyll $a$ concentrations and production of MAAs (mycosporine- like amino acids) in three lotic macroalgae, C. glomerata (Chlorophyta), Spirogyra sp. (Streptophyta) and S. delicatula (Rhodophyta) in response to UV radiation exposure (PAR + UVA, PAR + UVAB and PAR-only).

Based on the assumptions that: (1) C. glomerata, Spirogyra sp. and $S$. delicatula are freshwater macroalgae regularly exposed to high solar radiation, including high doses of UVB and UVA, due to their wide distribution in shallow habitats; (2) compared to marine macroalgae, information on the UV-protective mechanisms in freshwater macroalgae is scarce (Roleda et al. 2010); (3) red and green are typically shade and sun-adapted algae, respectively (Necchi 2004, 2005), we hypothesized that: (i) Spirogyra sp. and $C$. glomerata are expected to present similar photosynthetic performances with slight responses to exposure of UVA and UVAB radiation; and (ii) $S$. delicatula is predicted to exhibit a higher sensitivity to UV exposure.

\section{Material and methods}

\subsection{Biological material}

Cladophora glomerata was collected in Preto River $\left(20^{\circ} 52^{\prime} \mathrm{S}, 49^{\circ} 19^{\prime} \mathrm{W}\right)$, Engenheiro Schmidt District, Preto River, municipality of São José do Rio Preto, São Paulo State, Brazil $\left(20^{\circ} 52^{\prime} \mathrm{S}, 49^{\circ} 19^{\prime} \mathrm{W}\right)$, in a shaded river segment (irrradiance of $104 \pm 11 \mu \mathrm{mol}$ photons $\mathrm{m}^{-2} \mathrm{~s}^{-1}$ ) and under temperature of $19.2{ }^{\circ} \mathrm{C}$. Spirogyra sp. and $S$. delicatula were collected in Talhadinho Stream $\left(20^{\circ} 43^{\prime} \mathrm{S}, 49^{\circ} 13^{\prime} \mathrm{W}\right)$, São José do Rio Preto, São Paulo State, Brazil. Both species were collected in different dates in a partly shaded stream segment with the following irradiance and temperature: $910 \pm 163 \mu \mathrm{mol}$ photons $\mathrm{m}^{-2} \mathrm{~s}^{-1}$ and $25.3^{\circ} \mathrm{C}$ (Spirogyra sp.) and $1049 \pm 86 \mu \mathrm{mol}$ photons $\mathrm{m}^{-2} \mathrm{~s}^{-1}$ and $22.6{ }^{\circ} \mathrm{C}$ (S. delicatula). Data on PAR, UVA and UVB radiation measured in the field are presented in Table S1 (Supplementary Material).

\subsection{Experimental design}

After collection, algal thalli were transported to the laboratory and were cleaned of debris and visible epiphytes under a stereoscope. Then, they were transferred to $1 \mathrm{~L}$ vessels containing water from the collecting sites, previously filtered and autoclaved. They were acclimated for $24 \mathrm{~h}$ under the following conditions: PAR $\left(179 \pm 18 \mu \mathrm{mol}\right.$ photons $\mathrm{m}^{-2} \mathrm{~s}^{-1}$, $22.0 \pm 2.0^{\circ} \mathrm{C}, 12: 12 \mathrm{~h}$ photoperiod). Radiation was supplied by cool-white fluorescent lamps Osram L $15 \mathrm{~W}$ "cool daylight" (Osram, Hildesheim, Germany). Algal thalli under these conditions were used as the control (designated Pre-pre-treatment). 
Three treatments (with five replicates) were performed for each species: (1) PAR (400-700 nm), P treatment; (2) PAR + UVA (320-700 nm), named $\mathrm{PA}$ treatment; (3) $\mathrm{PAR}+\mathrm{UVA}+\mathrm{UVB}$ (280-700 nm), designated as PAB treatment. All treatments were provided by two cool white fluorescent lamps Osram L 15 W "cool daylight" (Osram, Hildesheim, Germany), covered with neutral black mesh and by one Ultra-Vitalux $300 \mathrm{~W}$ lamp, $230 \mathrm{~V}$ E27/ES (Osram, Hildesheim, Germany). Radiation treatments were obtained with placing cut off filters in front of the samples (Figueroa et al. 1997, 2003; Roleda et al. 2010). P treatment used filter Lee n. 226, blocking UVA (320-400 nm) and UVB radiation (280-320 nm). PA treatment used filter Lee n.130, blocking UVB radiation, whereas for PAB treatment (3) no filter was applied, being submitted to the entire spectra provided by the lamps. Algal thalli were maintained for 10 days under these conditions with a photoperiod of $12 \mathrm{~h}$ (Bautista-Saraiva et al. 2017). Average irradiance level in each treatment was $179 \pm 18 \mu \mathrm{mol}$ photons $\mathrm{m}^{-2} \mathrm{~s}^{-1}$ to simulate the irradiance described as favorable in the literature for freshwater macroalgae (Necchi 2004). Absolute irradiance $\left(\mathrm{W} \mathrm{m}^{-2}\right)$ was measured with the spectroradiometer UV-Visible USB2000 + RAD (Ocean Optics, Dunedin, USA). The UVB/UVA ratio was 0.25 in laboratory close to that measured in the field (0.22, Table S1, Supplementary Material).

Incubations were performed at $22.0 \pm 2.0^{\circ} \mathrm{C}$ in refrigerated incubators Marconi, MA mod 830/A (Marconi Equipment for Laboratory, Piracicaba, Brazil), with orbital agitation of $100 \pm 5 \mathrm{rpm}$. To ensure uniform irradiation of all samples, replicate positions were changed every 2 days during the experiment. Thalli were incubated in UV-transparent $300 \mathrm{~mL}$ metacrylate plastic vessels. Incubations were conducted in water from the collecting sites, previously filtered and autoclaved, which was changed every 2 days in order to avoid nutrients and $\mathrm{CO}_{2}$ limitation, as well as excessive water evaporation. The initial fresh weights for each replicate were $35.0 \pm 5.0 \mathrm{mg}($ C. glomerate $), 235.0 \pm 5.0 \mathrm{mg}$ (Spirogyra sp.) and $145.0 \pm 5.0$ (S. delicatula) $\mathrm{mg}$ fresh weight $(\mathrm{FW})$.
2.3 Photosynthetic performance as in vivo chlorophyll $a$ fluorescence

In vivo chlorophyll $a$ fluorescence was measured using a Diving-PAM underwater fluorometer (Walz, Effeltrich, Germany). Algal thalli were placed directly on the tip of the fluorometer optic fiber using the supplied magnet sample holder. The biomass was high enough to cover the area of the fluorometer optic fiber tip.

Photosynthesis-irradiance (P-E) curves, as rapid light curves (White and Critchley 1999), consisted of the fluorescence responses to eight increasing irradiances from 0 to $792 \mu \mathrm{mol} \mathrm{m}{ }^{-2} \mathrm{~s}^{-1}$, using the "light curve" option of the Diving-PAM. The exposure time at each irradiance was $15 \mathrm{~s}$, each separated by a saturating flash $\left(0.8 \mathrm{~s}, \sim 6000 \mu \mathrm{mol} \mathrm{m} \mathrm{m}^{-2} \mathrm{~s}^{-1}\right)$. The calculations and terminology followed Schreiber et al. (1994) and van Kooten and Snel (1990), respectively. The following parameters were determined from each sample: (1) effective quantum yield of PSII, $\Delta F /$ $F_{\mathrm{m}}{ }^{\prime}=\left(F_{\mathrm{m}}{ }^{\prime}-F_{\mathrm{t}}\right) / F_{\mathrm{m}}{ }^{\prime}$, being $F_{\mathrm{m}}{ }^{\prime}$ maximal fluorescence of light acclimated thalli and $F_{\mathrm{t}}$ the transient fluorescence of light-acclimated thalli; (2) non-photochemical quenching $(N P Q)$ was determined as $N P Q=\left(F_{\mathrm{m}}-F_{\mathrm{m}}{ }^{\prime}\right) / F_{\mathrm{m}}{ }^{\prime}$. (3) Electron transport rate (ETR) was calculated as $\mathrm{ETR}=\Delta F / F_{\mathrm{m}}{ }^{\prime} \times E_{\mathrm{PAR}}(-$ $\mu$ mol photons $\left.\mathrm{m}^{-2} \mathrm{~s}^{-1}\right) \times \mathrm{A} \times \mathrm{F}_{\mathrm{II}}$ being $E_{\mathrm{PAR}}$ the incident irradiance of PAR in $\mu \mathrm{mol} \mathrm{m} \mathrm{m}^{-2} \mathrm{~s}^{-1}$. A was the absorptance, or fraction of light absorbed by PSII in an optical cross section. It was estimated for each alga tested (0.89 to C. glomerata, 0.69 to Spirogyra sp. and 0.78 to $S$. delicatula), based on measurements taken with and without the alga within a circle of $0.5 \mathrm{~cm}$ in diameter, similar to the area of the fluorometer optic fibertip (Necchi 2004; Bautista and Necchi 2007). $F_{I I}$ is the fraction of chlorophyll $a$ associated to photosystem II. $\mathrm{F}_{\text {II }}$ in red and green macroalgae is assumed to have a value of 0.15 and 0.5 , respectively (Johnsen and Sakshaug 2007; Figueroa et al. 2014). Based on the ETR versus irradiance curves measured for each treatment, maximum electron transport rate $\left(\mathrm{ETR}_{\max }\right)$, photosynthetic efficiency $\left(\alpha_{\mathrm{ETR}}\right)$, saturation parameter $\left(E_{\mathrm{k}}\right)$ and the slope of photoinhibition $\left(\beta_{\mathrm{ETR}}\right)$ were obtained by fitting these curves to the tangential fitting reported by Platt et al. (1980).

Dark/light induction-recovery (Kautsky) curves were performed on thalli dark-acclimated to determinate of maximal quantum yield and to assess the 
recovery capacity. For dark acclimation, apices of algal thalli were placed for 10 min directly on the tip of the fiberoptic using the supplied dark leaf clip determining the basal fluorescence $\left(F_{\mathrm{o}}\right)$ and maximal fluorescence $\left(F_{\mathrm{m}}\right)$ after a saturating light pulse $\left(0.8 \mathrm{~s}, \sim 6000 \mu \mathrm{mol} \mathrm{m}{ }^{-2} \mathrm{~s}^{-1}\right)$. First, a saturation pulse was applied for determination of maximal quantum yield of PSII, $F_{\mathrm{v}} / F_{\mathrm{m}}$, being $F_{\mathrm{v}}=F_{\mathrm{m}}-F_{\mathrm{o}}$ (Schreiber et al. 1994). Then, a constant actinic irradiance $\left(221 \mu \mathrm{mol}\right.$ photons $\mathrm{m}^{-2} \mathrm{~s}^{-1}$, close to the incubation irradiance) was applied using the halogen light source of the Diving PAM, separated by eight saturating light pulses at $15 \mathrm{~s}$ intervals, and initiated $30 \mathrm{~s}$ after the first saturation pulse. After recording of dark/light induction, six saturation pulses were applied at successive intervals $(10,30,60 \mathrm{~s}$ and 2,5 and $10 \mathrm{~min}$ ) to assess the dark recovery of $F_{\mathrm{v}} / F_{\mathrm{m}}$, by comparing the initial and final values.

\subsection{Chlorophyll $a$ content}

Chlorophyll $a(\mathrm{Chl} a)$ concentrations were evaluated at the end of the experiment, after measurements of the photosynthetic parameters. They were calculated according to the protocol by Ritchie (2006). Plants were kept frozen until the analysis. The material was grinded in the darkness in a Precellys 24 tissue homonogenizer (Bertin Technologies). Subsequent extraction of chlorophyll $a$ was conducted in $1 \mathrm{~mL}$ of $90 \%$ alkaline acetone in darkness at $4{ }^{\circ} \mathrm{C}$. Samples were centrifuged in a Mikro 220R centrifuge (Hettich) at $4000 \mathrm{rpm}, 4{ }^{\circ} \mathrm{C}$ for $20 \mathrm{~min}$ and chlorophyll $a$ was quantified according to the spectrophotometric technique using the equation according to Ritchie (2006, 2008).

\subsection{Mycosporine-like amino acids-MAAs}

Considering that Rhodophyta has the highest percentage of species that synthesize MAAs (Barufi et al. 2011) among the various groups of macroalgae, while only a few macroscopic green algal species contain MAA-like UV-absorbing compounds, (Holzinger et al. 2006; Pescheck et al. 2010), quantification of this parameter was carried out only for the red alga $S$. delicatula.

After the experimental periods, samples of $20.0 \pm 5.0 \mathrm{mg}$ DW were processed according to the protocol used in a previous study (Bautista-Saraiva et al. 2017) for the extraction and identification of mycosporine-like amino acids (MAAs). They were extracted in $1 \mathrm{~mL}$ of $20 \%$ aqueous methanol (v/v) for $2 \mathrm{~h}$ at $45^{\circ} \mathrm{C}$, centrifuged at $13,000 \mathrm{~g}, 4^{\circ} \mathrm{C}$ for $10 \mathrm{~min}$ and a total of $100 \mu \mathrm{L}$ of the supernatant was filtered and transferred to glass tubes in the HPLC Waters system (Barcelona, Spain).

MAAs were detected by using an isocratic run containing $2.5 \%$ aqueous methanol (v/v) plus $0.1 \%$ acetic acid (v/v) in distilled water as the mobile phase. The flow rate was $0.5 \mathrm{~mL} \mathrm{~min}^{-1}$ and each run took $20 \mathrm{~min} ; 30 \mu \mathrm{L}$ of the each sample was injected into a Sphereclone C8 column (Phenomenex, Germany) with a pre-column attached (5-mm packing; $250 \times 4 \mathrm{~mm}$ I.D.). MAAs were detected with a Waters Photodiode Array Detector 996 (Barcelona, Spain). The absorption spectra were recorded between 290 and $400 \mathrm{~nm}$ every second. Finally, a chromatogram selected for absorbance at $330 \mathrm{~nm}$ was obtained, and the observed peaks were identified according to the spectrum and retention time, compared with a secondary standard of Porphyra leucosticta. MAAs were quantified according to KorbeePeinado et al. (2004). Data were collected and analyzed with the Millennium 3.2 software.

\subsection{Data analysis}

Data set was analyzed using one-way ANOVA and post hoc multiple comparisons applying NewmanKeuls post hoc multi-comparative analysis to identify differences in photosynthetic parameters and pigments (chlorophyll $a$ and MAAs). The factor evaluated was the difference between Pre (Control) and treatments (P, PA and PAB). Statistical tests were performed with GraphPad Prism 5.01 software, whereas graphs and calculations from P-E curve parameters were made using Microsoft Excel 2013.

\section{Results}

P-E curves revealed different responses to UV radiation among the three freshwater macroalgae (Table 1; Fig. 1). Cladophora glomerata had higher ETR $_{\max } \quad\left(19.69-22.37 \mu \mathrm{mol} \mathrm{e}^{-} \mathrm{m}^{-2} \mathrm{~s}^{-1}\right), \quad \alpha_{\text {ETR }}$ (0.014-0.178) and $E_{\mathrm{k}}(125.51-141.38)$ than Spirogyra sp., whereas $S$. delicatula presented lower values of ETR $_{\max }$ and $\alpha_{\text {ETR }}$ (Table 1; Fig. 1). This species 
Table 1 Parameters derived from the $\mathrm{P}-\mathrm{E}$ curves, corresponding to Fig. 1, and Chlorophyll $a$ content $(\mathrm{Chl} a)$ comparing Pre (initial-control), P, PA and PAB in Cladophora glomerata, Spirogyra sp. and Sirodotia delicatula after 10 days
Data are expressed as means \pm standarddeviation $(\mathrm{n}=5$ for $\mathrm{P}, \mathrm{PA}$ and $\mathrm{PAB} ; \mathrm{n}=15$ for control). Distinct letters indicate significant differences $(\mathrm{p}<0.05)$ by ANOVA (Newman-Keuls Post-hoc)

\begin{tabular}{|c|c|c|c|c|}
\hline & Treatment & C. glomerata & Spirogyra sp. & S. delicatula \\
\hline $\mathrm{ETR}_{\max }$ & Pre & $22.37 \pm 3.02^{\mathrm{a}}$ & $15.56 \pm 3.37^{\mathrm{a}}$ & $2.89 \pm 0.52^{\mathrm{a}}$ \\
\hline$(\mu \mathrm{mol}$ & $\mathrm{P}$ & $21.43 \pm 5.67^{\mathrm{a}}$ & $5.43 \pm 3.45^{\mathrm{b}}$ & $1.24 \pm 0.13^{\mathrm{b}}$ \\
\hline \multirow[t]{2}{*}{ electrons $\mathrm{m}^{-2} \mathrm{~s}^{-1}$ ) } & PA & $19.69 \pm 1.87^{\mathrm{a}}$ & $8.43 \pm 1.77^{\mathrm{b}}$ & $1.22 \pm 0.16^{\mathrm{b}}$ \\
\hline & $\mathrm{PAB}$ & $19.86 \pm 0.48^{\mathrm{a}}$ & $6.09 \pm 2.30^{\mathrm{b}}$ & $1.24 \pm 0.09^{\mathrm{b}}$ \\
\hline$E_{k}$ & Pre & $125.51 \pm 8.61^{\mathrm{a}}$ & $95.44 \pm 17.09^{\mathrm{a}}$ & $45.98 \pm 8.72^{\mathrm{a}}$ \\
\hline ( $\mu$ mol photons & $\mathrm{P}$ & $141.38 \pm 13.12^{\mathrm{b}}$ & $83.23 \pm 24.52^{\mathrm{a}}$ & $83.70 \pm 9.39^{b}$ \\
\hline \multirow[t]{2}{*}{$\left.\mathrm{m}^{-2} \mathrm{~s}^{-1}\right)$} & PA & $134.68 \pm 6.64^{\mathrm{a}, \mathrm{b}}$ & $127.61 \pm 15.49^{b}$ & $86.71 \pm 2.66^{\mathrm{b}}$ \\
\hline & $\mathrm{PAB}$ & $133.59 \pm 1.95^{\mathrm{a}, \mathrm{b}}$ & $84.27 \pm 22.73^{\mathrm{a}}$ & $86.52 \pm 7.23^{\mathrm{b}}$ \\
\hline \multirow[t]{4}{*}{$\alpha_{\text {ETR }}$} & Pre & $0.178 \pm 0.014^{\mathrm{a}}$ & $0.158 \pm 0.014^{\mathrm{a}}$ & $0.060 \pm 0.010^{\mathrm{a}}$ \\
\hline & $\mathrm{P}$ & $0.150 \pm 0.027^{\mathrm{b}}$ & $0.061 \pm 0.020^{\mathrm{b}}$ & $0.015 \pm 0.002^{\mathrm{b}}$ \\
\hline & PA & $0.149 \pm 0.011^{\mathrm{b}}$ & $0.066 \pm 0.012^{\mathrm{b}}$ & $0.015 \pm 0.002^{\mathrm{b}}$ \\
\hline & $\mathrm{PAB}$ & $0.149 \pm 0.004^{\mathrm{b}}$ & $0.073 \pm 0.018^{\mathrm{b}}$ & $0.014 \pm 0.001^{\mathrm{b}}$ \\
\hline \multirow[t]{4}{*}{$\beta_{\text {ETR }}$} & Pre & $20.01 \pm 1.34^{\mathrm{a}}$ & $26.44 \pm 5.30^{\mathrm{a}}$ & $48.20 \pm 7.76^{\mathrm{a}}$ \\
\hline & $\mathrm{P}$ & $17.81 \pm 1.71^{\mathrm{b}}$ & $31.62 \pm 8.08^{\mathrm{a}}$ & $30.19 \pm 3.35^{\mathrm{b}}$ \\
\hline & PA & $18.96 \pm 1.23^{\mathrm{a}, \mathrm{b}}$ & $19.79 \pm 2.31^{\mathrm{a}}$ & $30.43 \pm 3.35^{\mathrm{b}}$ \\
\hline & PAB & $18.72 \pm 0.27^{\mathrm{a}, \mathrm{b}}$ & $31.93 \pm 10.78^{\mathrm{a}}$ & $29.09 \pm 2.58^{\mathrm{b}}$ \\
\hline \multirow[t]{3}{*}{ Chla } & $\mathrm{P}$ & $0.03 \pm 0.01^{\mathrm{a}}$ & $0.02 \pm 0.01^{\mathrm{a}}$ & $0.08 \pm 0.04^{\mathrm{a}}$ \\
\hline & PA & $0.04 \pm 0.01^{\mathrm{a}}$ & $0.02 \pm 0.01^{\mathrm{a}}$ & $0.04 \pm 0.01^{\mathrm{a}}$ \\
\hline & PAB & $0.01 \pm 0.01^{\mathrm{b}}$ & $0.02 \pm 0.01^{\mathrm{a}}$ & $0.05 \pm 0.02^{\mathrm{a}}$ \\
\hline
\end{tabular}

presented significantly higher values in Pre (Control) for $\alpha_{\mathrm{ETR}}(\mathrm{F}=7.84, p<0.01)$, and no significant difference was observed for ETR $_{\max }$. As consequence, higher values of $E_{\mathrm{k}}$ were observed in treatments, but significant differences were found only in $\mathrm{P}(\mathrm{F}=4.3$, $p<0.05)$. Higher values of photoinhibition parameter $\left(\beta_{\mathrm{ETR}}\right)$ were observed in control, but significant difference was found only in $\mathrm{P}(\mathrm{F}=3.89, p<0.05)$. $N P Q$ was significantly higher in $\mathrm{PA}$ and $\mathrm{PAB}$ than in control and $\mathrm{P}(\mathrm{F}=54.06, p<0.0001)$, while significantly lower values of $\Delta \mathrm{F} / F_{\mathrm{m}}{ }^{\prime}(\mathrm{F}=13.56, p<0.001)$ and of $F_{\mathrm{v}} / F_{\mathrm{m}}(\mathrm{F}=4.70, p<0.01)$ were observed in PA (Fig. 2). Higher recovery capacity of $F_{\mathrm{v}} / F_{\mathrm{m}}$ was found in PA $(\mathrm{F}=21.97, p<0.0001)$.

Spirogyra sp. had significantly higher values in control for $\mathrm{ETR}_{\max }(\mathrm{F}=19.10, p<0.0001)$ and $\alpha_{\mathrm{ETR}}$ $(\mathrm{F}=7.84, p<0.01)$ (Table 1; Fig. 1) and significant differences for $E_{\mathrm{k}}$ were found only in PA $(\mathrm{F}=4.86$, $p<0.01)$. No significant differences were found for $N P Q$, except for $\mathrm{P}$ that showed lower values of NPQ ( $\mathrm{F}=7.41, p<0.05)$ (Fig. 2). Although Spirogyra sp., in general, showed higher values in control, an increase of photosynthetic performance $\left(\Delta F / F_{\mathrm{m}}{ }^{\prime}\right.$ and $\left.F_{\mathrm{v}} / F_{\mathrm{m}}\right)$ was observed in $\mathrm{PA}$ and $\mathrm{PAB}(\mathrm{F}=32.48$, $p<0.0001$ for $\Delta F / F_{\mathrm{m}}{ }^{\prime}$ and $\mathrm{F}=18.95, p<0.0001$ for
$\left.F_{\mathrm{v}} / F_{\mathrm{m}}\right)$ (Fig. 2). In contrast, significantly lower values of recovery capacity of $F_{\mathrm{v}} / F_{\mathrm{m}}$ were found in PA and $\mathrm{PAB}(\mathrm{F}=4.37, p<0.05)$.

Sirodotia delicatula had significantly higher values in control for $\mathrm{ETR}_{\max }(\mathrm{F}=44.96, p<0.0001)$, $\alpha_{\mathrm{ETR}}$ $(\mathrm{F}=58.45, \quad p<0.0001)$ and $\beta_{\mathrm{ETR}} \quad(\mathrm{F}=21.85$, $p<0.0001$ ), while lower values in control were found for $E_{\mathrm{k}}(\mathrm{F}=54.32, p<0.0001)$ (Table 1; Fig. 1). $N P Q$ was significantly higher in $\mathrm{P}, \mathrm{PA}$ and $\mathrm{PAB}(\mathrm{F}=13.48$, $p<0.0001)$, while significantly lower values were observed for $F_{\mathrm{v}} / F_{\mathrm{m}}$ in all treatments $(\mathrm{F}=24.66$, $p<0.0001$ ) (Fig. 2). No increase or decrease between treatments were observed for $\Delta F / F_{\mathrm{m}}{ }^{\prime}$ and recovery capacity of $F_{\mathrm{v}} / F_{\mathrm{m}}$.

Chlorophyll a concentrations were significantly lower $(\mathrm{F}=9.56 ; \mathrm{p}<0.01)$ in PAB for $C$. glomerata, whereas in Spirogyra sp. and S. delicatula no significant differences were observed among treatments (Table 1).

Shinorine and palythine were the two types of MAAs identified in $S$. delicatula, with shinorine corresponding to $80 \%$ of the total MAAs found in this species (Fig. 3). The content of MAAs was higher under $\mathrm{P}$ compared to $\mathrm{PA}$ and $\mathrm{PAB}$ treatments with significant decrease of MAAs concentrations found 

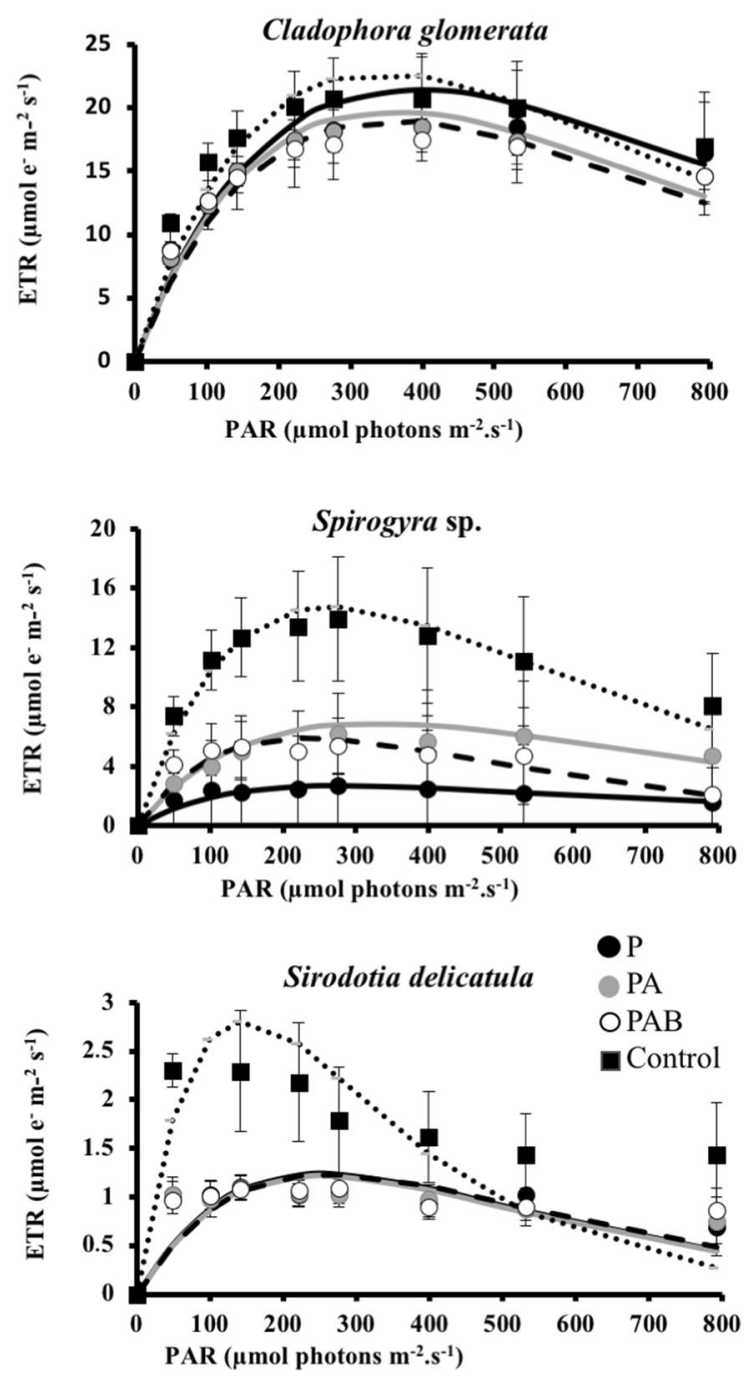

Fig. 1 P-E curves for Cladophora glomerata, Spirogyra sp. and Sirodotia delicatula under Pre (Control) and UVR treatments (P, PA and PAB). Data are expressed as means $\pm \mathrm{s}-$ tandard-deviation. $(\mathrm{n}=5$ for $\mathrm{P}, \mathrm{PA}$ and $\mathrm{PAB} ; \mathrm{n}=15$ for Control)

among UV treatments $(\mathrm{F}=14.17 ; \mathrm{p}<0.01$ for shinorine; $\mathrm{F}=11.18 ; \mathrm{p}<0.01$ for palythine; $\mathrm{F}=22.28 ; \mathrm{p}<0.01$ for total MAAs) (Fig. 3).

\section{Discussion}

The three tropical lotic macroalgae studied were characterized as either sun-adapted (C. glomerata) and shade-adapted ( $S$. delicatula) or with intermediate characteristics (Spirogyra sp.) according to their responses of photosynthetic parameters to artificial UV exposure. Sirodotia delicatula showed lower values of $\mathrm{ETR}_{\max }$ and $E_{\mathrm{k}}$ and higher values of photoinhibition $\left(\beta_{\mathrm{ETR}}\right)$, typical of shaded-adapted algae. Adaptations to low irradiance were consistently observed for Rhodophyta (Necchi and Zucchi 2001; Necchi 2004). In contrast, most species of Chlorophyta has been reported as sun-adapted algae (Graham et al. 1995; Ensminger et al. 2001; Necchi 2004). While C. glomerata revealed typical responses of a sun-adapted plant, with higher ETR $\mathrm{max}_{\max }$ and $E_{\mathrm{k}}$, and lower values of $\beta_{\mathrm{ETR}}$, Spyrogyra sp. could be fitted in an intermediate group in terms of light adaptations.

Studies on UV effects on macroalgae have been typically focused on UVB radiation (Altamirano et al. 2000; Hanelt et al. 2006), and a question, which is still a matter of debate, is whether all the different bands of UV spectra (UVA and UVB) are damaging or possibly beneficial (Altamirano et al. 2000) to these organisms. Although P-E curves have revealed different responses to PAR acclimations for the three macroalgal species in this study, the way that photosynthesis was affected by UV radiation was distinct, no matter if they were sun- or shade-adapted algae.

A decrease of the $F_{\mathrm{v}} / F_{\mathrm{m}}$ level and an increase of $N P Q$ values were more pronounced under UVA than UVAB radiation in the three species tested, although significant lower values in recovery capacity of $F_{\mathrm{v}} / F_{\mathrm{m}}$ and in chlorophyll $a$ content under UVAB radiation had been showed only for $C$. glomerata. Ensminger et al. (2001) found that $N P Q$ values increased rapidly with the increase of irradiance for both high-light (open site) and shaded plants of $C$. glomerata. In addition, a decrease of $F_{\mathrm{v}} / F_{\mathrm{m}}$ was interpreted as an indicator of the photoinhibition effect on photosynthesis (Figueroa et al. 2009), revealing amplified excitation pressure on photosystem II in C. glomerata. The decrease in $F_{\mathrm{v}} / F_{\mathrm{m}}$ under different conditions of UV radiation was associated with a gradual decrease in chlorophyll contents in two species of the marine green alga Ulva (Figueroa et al. 2003). Pigment contents give us important elements about the state of the photosynthetic apparatus. However, because the pigments are not directly linked to photosynthetic UV acclimation, their concentrations are usually considered to be a weak biological indicator of the effects of UV radiation under such experimental designs (Figueroa et al. 2003). 

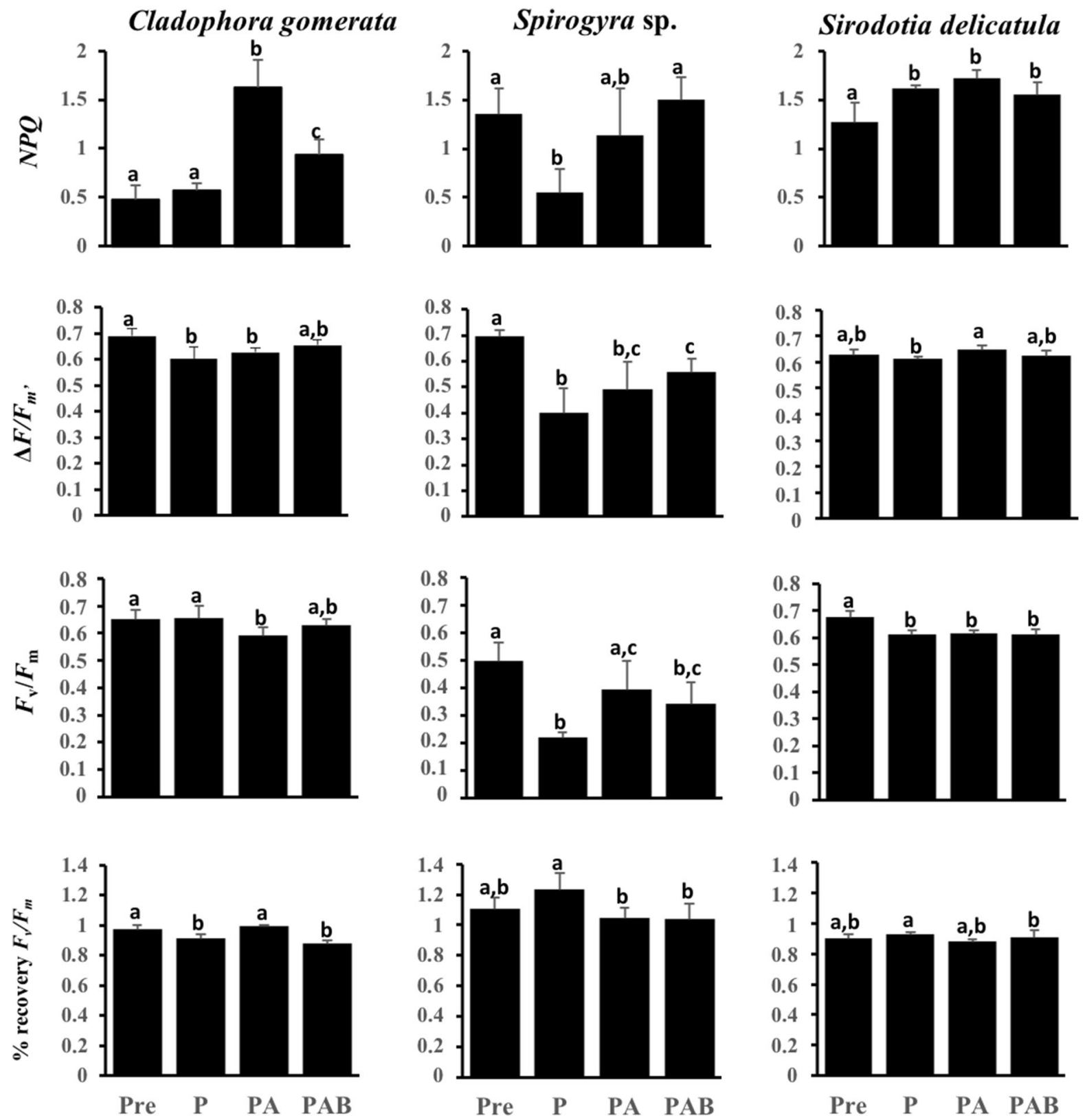

Fig. 2 Photosynthetic parameters (NPQ, $\Delta \mathrm{F} / F_{\mathrm{m}}{ }^{\prime}, F_{\mathrm{v}} / F_{\mathrm{m}}$ and recovery capacity of $\left.F_{\mathrm{v}} / F_{\mathrm{m}}\right)$ for Cladophora glomerata, Spirogyra sp. and Sirodotia delicatula under Pre (Control) and UVR treatments ( $\mathrm{P}, \mathrm{PA}$ and $\mathrm{PAB})$. Data are expressed as

We generally observed higher values of $N P Q, \Delta F /$ $F_{\mathrm{m}}{ }^{\prime}$ and $F_{\mathrm{v}} / F_{\mathrm{m}}$, under UVA and UVAB under PAR only in Spirogyra sp. In addition, although the recovery capacity of $F_{\mathrm{v}} / F_{\mathrm{m}}$ was lower under UVA and UVAB, it showed $100 \%$ recovery, indicating a high capacity to cope with UV radiation. The mostly good means \pm standard-deviation. $(\mathrm{n}=5$ for $\mathrm{P}, \mathrm{PA}$ and $\mathrm{PAB} ; \mathrm{n}=15$ for Control). Distinct letters indicate significant differences $(\mathrm{p}<0.05)$ by ANOVA (Newman-Keuls Post-hoc)

photosynthetic performance for Spirogyra sp. under UV radiation could be related to its capacity to tolerate high irradiances (Graham et al. 1995; Necchi 2004). Germ (2005) concluded that Spirogyra sp. have high physiological plasticity and resistance that may be enhanced by UVB radiation. Although most 


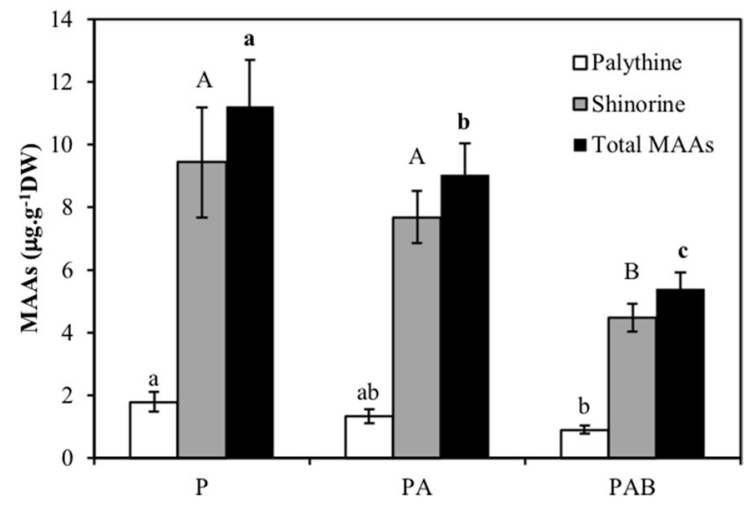

Fig. 3 Mycosporine-like amino acids (MAAs) of Sirodotia delicatula under P, PA and PAB treatments. Data are expressed as means \pm standard-deviation $(n=5)$. Distinct lower-case (Palythine and Total MAAs) and upper-case (Shinorine) letters indicate significant differences $(\mathrm{p}<0.05)$ by ANOVA (Newman-Keuls Post-hoc)

studies have reported a negative impact on photosynthesis by UV radiation, some investigations found beneficial effects of UVB and UVA by photoprotection of photosynthesis in algae (Figueroa et al. 2009). Photosynthesis in the green alga Dasycladus vermicularis significantly increased in plants exposed to PAR + UVA radiation (Pérez-Rodriguez et al. 1998). According to Figueroa et al. (2009), UVB could have a role in inducing and maintaining photoprotective mechanisms under high UV exposure. The exclusion of UVB was shown to produce a reduction of photosynthetic activity in Mediterranean (FloresMoya et al. 1999) and tropical algae (Hanelt and Roleda 2009). The photosynthetic performance of Ulva rigida (Chlorophyta) was always negatively affected under PAR alone compared to that in the presence of UV radiation (Altamirano et al. 2000).

High values of $N P Q$ may indicate active photoprotective mechanisms, which are highly related to the xanthophyll cycle (Demmig-Adams and Adams 2006). Schubert and García-Mendoza (2008) reported that the degree of decrease and recovery of $F_{\mathrm{v}} / F_{\mathrm{m}}$ and their respective kinetics were related to the carotenoid profile of the species. Choo et al. (2005) stated that photosynthesis in C. glomerata was inhibited by UVB radiation, and a defense mechanism against UVRinduced oxidative stress is enabled through an increase in carotenoid concentration and a functional xanthophyll cycle. It is plausible to expect an important role of carotenoids and $N P Q$ under UV radiation in $C$. glomerata and Spirogyra sp., but this will require further studies on carotenoid quantification, identification and interconversion.

Freshwater red algae have a typical response to irradiance, mostly being considered as shade-adapted algae (Necchi 2005; Bautista and Necchi 2007), although they are typically found in shallow parts of streams and rivers and, thus, are exposed to high solar radiation during some periods (Sheath and Hambrook 1990; Necchi 2005; Bautista and Necchi 2007). Thus, they are expected to have mechanisms to cope with such high irradiances, as shown in some previous studies (Necchi 2005; Bautista and Necchi 2007; Aigner et al. 2017). Necchi and Alves (2005) observed that $S$. delicatula exhibited a wide range of responses to irradiance regarding to photosynthetic characteristics. In this study, values of $N P Q, \Delta F / F_{\mathrm{m}}{ }^{\prime}, F_{\mathrm{v}} / F_{\mathrm{m}}$ and recovery capacity of $F_{\mathrm{v}} / F_{\mathrm{m}}$ revealed that this alga is essentially insensitive to UVA and UVAB radiation, corroborating studies that it could tolerate not only high irradiances but also UV radiation. Aigner et al. (2017) reported that exposure to either UVA or UVAB led to a strong transient drop in effective quantum yield in B. turfosum, but that alga was capable of recovering after being removed from UVR treatment.

The synthesis and accumulation of photoprotective compounds, such as mycosporine-like amino acids (MAAs), is one of the strategies used by macroalgae under exposure to high levels of UV (Sinha and Häder 2002; Häder et al. 2015; Navarro et al. 2016). Rhodophyta is the algal group that has the highest percentage of species that synthesize MAAs (Barufi et al. 2011). Two types of MAAs were identified in $S$. delicatula-shinorine and palythine, with the former corresponding to approximately $80 \%$ of the total MAAs found in this alga. Both MAAs were found in very low quantities in comparison to marine red algae (Karsten et al. 1998; Huovinen et al. 2004), similar to other freshwater red algal species, K. ambigua (Bautista-Saraiva et al. 2017) but quite different from L. fluviatilis that had remarkably high amounts (Arróniz-Crespo et al. 2005).

Although a decrease of MAAs concentrations were found between UV treatments, the presence of MAAs suggests that this substance was produced to avoid photodamage of the photosynthetic apparatus. Arróniz-Crespo et al. (2005) have also reported similar results in which MAA concentrations remained stable under $\mathrm{P}$ and PA regimes and decreased under 
PAB. This could be explained by the apparent universal sensitivity of MAA to UV-B radiation (Sinha et al. 2000; Ryan et al. 2002). MAAs have been reported so far in three members of the freshwater red algal order Batrachospermales (Arróniz-Crespo et al. 2005; Bautista-Saraiva et al. 2017; this study), whereas they have not been detected in B. turfosum by Aigner et al. (2017).

The two typical sun-adapted lotic green macroalgae, C. glomerata and Spirogyra sp., presented distinct responses to exposure of UV radiation as regard to photosynthetic performance and chlorophyll $a$ concentration. A more pronounced decrease of $F_{\mathrm{v}} / F_{\mathrm{m}}$ and increase of $N P Q$ under UVA than UVAB was observed, although chlorophyll $a$ content was lower under UVAB in $C$. glomerata. Spirogyra sp. had a decrease of photosynthesis $\left(\Delta F / F_{\mathrm{m}}{ }^{\prime}\right.$ and $\left.F_{\mathrm{v}} / F_{\mathrm{m}}\right)$ indicating that UVAB radiation is an important source energy in the photosynthetic apparatus. Surprisingly, S. delicatula, a shaded-adapted red alga, exhibited less sensitivity to UV exposure. These results suggest that the presence of MAAs is a significant shield of protection against UV radiation. The plasticity of photosynthesis is a major attribute that enables autotrophic organisms to balance energy conversion and energy consumption by acclimation of the photosynthetic apparatus (Ensminger et al. 2001) and, thus, they are able to cope with light climate variations in terms of global changes.

Acknowledgements Authors are grateful to Francieli Ruiz da Silva for statistical advice and to Maria Helena Carabolante for help in laboratory work. We acknowledge the São Paulo Research Foundation (FAPESP) and National Council for Scientific and Technological Development (CNPq) for research Grants to ONJ.

\section{References}

Aigner S, Holzinger A, Karsten U, Kranner I (2017) The freshwater red alga Batrachospermum turfosum (Florideophyceae) can acclimate to a wide range of light and temperature conditions. Eur J Phycol 52:238-249. https://doi.org/10.1080/09670262.2016.1274430

Altamirano M, Flores-Moya A, Figueroa FL (2000) Long-term effects of natural sunlight under various ultraviolet radiation conditions on growth and photosynthesis of intertidal (Chlorophyceae) cultivated in situ. Bot Mar 43:119-126. https://doi.org/10.1515/BOT.2000.012

Arróniz-Crespo M, Sinha RP, Martínez-Abaigar J, Nuñez-Oliveiera E, Häder DP (2005) Ultraviolet radiation-induced changes in mycosporine-like amino acids and physiological variables in the red alga Lemanea fluviatilis. J Freshw Ecol 20:677-687. https://doi.org/10.1080/02705060.2005. 9664791

Barufi J, Korbee N, Oliveira MC, Figueroa FL (2011) Effects of $\mathrm{N}$ supply on the accumulation of photosynthetic pigments and photoprotectors in Gracilaria tenuistipitata (Rhodophyta) cultured under UV radiation. J Appl Phycol 23:457-466. https://doi.org/10.1007/s10811-010-9603-x

Bautista AIN, Necchi O Jr. (2008) Photoacclimation in a tropical population of Cladophora glomerata (L.) Kützing 1843 (Chlorophyta) from southeastern Brazil. Braz J Biol 68:129-136. https://doi.org/10.1590/S151969842008000100018

Bautista AIN, Necchi O Jr. (2007) Photoacclimation in three species of freshwater red algae. Braz J Plant Physiol 19:23-34. https://doi.org/10.1590/S167704202007000100003

Bautista-Saraiva AIN, Bonomi-Barufi J, Figueroa FL, Necchi O $\mathrm{Jr}$ (2017) UV-radiation effects on photosynthesis and photoprtection in gametophytic and sporophytic stages of the freshwater red alga Kumanoa ambigua (Rhodophyta, Batrachospermales). Phycol Res 66:108-116. https://doi. org/10.1111/pre.12209

Choo KS, Nilsoon J, Pedersén M, Snoeijs P (2005) Photosynthesis, carbon uptake and antioxidant defence in two coexisting filamentous green algae under different stress conditions. Mar Ecol Prog Ser 292:127-138. https://doi. org/10.3354/meps 292127

Demmig-Adams B, Adams WIII (2006) Photoprotection in an ecological context: the remarkable complexity of thermal dissipation. New Phytol 172:11-21. https://doi.org/10. 1111/j.1469-8137.2006.01835.x

Dodds WK, Gudder DA (1992) The ecology of Cladophora in freshwaters. J Phycol 28:415-427. https://doi.org/10.1111/ j.0022-3646.1992.00415.x

Ensminger I, Hagen C, Braune W (2000) Strategies providing success in a variable habitat: II. Ecophysiology of photosynthesis of Cladophora glomerata. Plant Cell Environ 23:1129-1136. https://doi.org/10.1046/j.1365-3040.2000. 00619.x

Ensminger I, Xyländer M, Hagen C, Braune W (2001) Strategies providing success in a variable habitat. III. Dynamic control of photosynthesis in Cladophora glomerata. Plant Cell Environ 24:769-779. https://doi.org/10.1046/j.1365-3040. 2001.00725.x

Figueroa FL, Salles S, Aguilera J, Jiménez C, Mercado J, Viñegla B, Flores-Moya A, Altamirano M (1997) Effects of solar radiation on photoinhibition and pigmentation in the red alga Porphyra leucosticta. Mar Ecol Prog Ser 151:81-90. https://doi.org/10.3354/meps151081

Figueroa FL, Nygard C, Ekelund N, Gómez I (2003) Photobiological characteristics and photosynthetic UV responses in two Ulva species (Chlorophyta) from southern Spain. J Photochem Photobiol B 72:35-44. https://doi.org/10. 1016/j.jphotobiol.2003.09.002

Figueroa FL, Korbee N, Carrillo P, Medina-Sanchez JM, Mata M, Bonomi-Barufi J, Sánchez-Castillo PM (2009) The effects of UV radiation on photosynthesis estimated as chlorophyll fluorescence in Zygnemopsis decussata (Chlorophyta) growing in a high mountain lake (Sierra 
Nevada, Southern Spain). J Limnol 68:206-216. https:// doi.org/10.3274/JL09-68-2-05

Figueroa FL, Domínguez-González B, Korbee N (2014) Vulnerability and acclimation to increased UVB radiation in three intertidal macroalgae of different morpho-functional groups. Mar Environ Res 101:30-38

Flores-Moya A, Hanelt D, Figueroa FL, Altamirano M, Viñegla $B$, Salles S (1999) Involvement of solar UVB radiation in recovery of inhibited photosynthesis in the brown alga Dictyota dichotoma (Hudson) Lamouroux. J Photochem Photobiol 49:29-135

Germ M (2005) The response of green alga Spirogyra sp. to different levels of UVB radiation. Phyton 45:173-182

Graham JM, Lembi CA, Adrian HL, Spencer DF (1995) Physiological responses to temperature and irradiance in Spirogyra (Zygnematales, Charophyceae). J Phycol 31:531-540. https://doi.org/10.1111/j.1529-8817.1995. tb02546

Häder DP, Figueroa FL (1997) Photoecophysiology of marine macroalgae. J Photochem Photobiol 66:1-14

Häder D-P, Kumar HD, Smith RC, Worrest RC, Williamson CE, Wängberg SA, Rautio M, Rose KC, Gao K, Helbling E, Sinha RP, Worrest RC (2015) Effects of UV radiation on aquatic ecosystems and interactions with other environmental factors. Photochem Photobiol Sci 14:108-126. https://doi.org/10.1039/C0PP90040K

Hanelt D, Figueroa FL (2012) Physiological and photomorphogenic effects of light on marine macrophytes. In: Wencke C, Bishchof K (eds) Seaweed biology. Novile insighths into ecophysiology, ecology and utilization ecological studies, vol 219. Springer, Heidelberg, pp 3-23

Hanelt D, Roleda MY (2009) UVB radiation may ameliorate photoinhibition in specific shallow-water tropical marine macrophytes. Aquat Bot 91:6-12. https://doi.org/10.1016/ j.aquabot.2008.12.005

Hanelt D, Hawes I, Rae R (2006) Reduction of UVB radiation causes an enhancement of photoinhibition in high light stressed aquatic plants from New Zealand lakes. J Photochem Photobiol B 84:89-102. https://doi.org/10.1016/j. jphotobiol.2006.01.013

Holzinger A, Lütz C (2006) Algae and UV irradiation: effects on ultrastructure and related metabolic functions. Micron 37:190-207. https://doi.org/10.1016/j.micron.2005.10.015

Holzinger A, Karsten U, Lütz C, Wiencke C (2006) Ultrastructure and photosynthesis in the supralittoral green macroalga Prasiola crispa from Spitsbergen (Norway) under UV exposure. Phycologia 45:168-177. https://doi. org/10.2216/05-20.1

Huovinen P, Gómez I, Figueroa FL, Ulloa N, Morales V, Lovengreen C (2004) Ultraviolet-absorbing mycosporinelike aminoacids in red macroalgae from Chile. Bot Mar 47:21-29

Johnsen G, Sakshaug E (2007) Biooptical characteristics of PSII and PSI in 33 species (13 pigment groups) of marine phytoplankton, and the relevance for pulse amplitudemodulated and fast-repetition-rate fluorometry. J Phycol 43:1236-1251. https://doi.org/10.1111/j.1529-8817.2007. 00422.x

Karsten U, Sawall T, Hanelt D, Bishof Km Flores-Moya A, Figueroa FL, Wiencke C (1998) Contents of UV absorbing mycosporine-like aminoacids in macroalgae from polar to warm-temperate regions. Bot Mar 41:443-453

Korbee-Peinado N, Abdala-Díaz RT, Figueroa FL, Helbling EW (2004) Ammonium and UV radiation stimulate the accumulation of mycosporine-like amino acids in Porphyra columbina (Rhodophyta) from Patagonia, Argentina. J Phycol 40:248-259. https://doi.org/10.1046/j.15298817.2004.03013.x

Navarro NP, Figueroa FL, Korbee N, Mansilla A, Plastino EM, Amsler C (2016) Differential responses of tetrasporophytes and gametophytes of Mazzaella laminarioides (Gigartinales, Rhodophyta) under solar UV radiation. J Phycol 52:451-462. https://doi.org/10.1111/jpy.12407

Necchi O Jr (2004) Light-related photosynthetic characteristics of lotic macroalgae. Hydrobiologia 525:139-155. https:// doi.org/10.1023/B:HYDR.0000038861.18999.7b

Necchi O Jr (2005) Light-related photosynthetic characteristics of freshwater rhodophytes. Aquat Bot 82:193-209. https:// doi.org/10.1016/j.aquabot.2005.02.010

Necchi O Jr (2016) An overview of river algae. In: Necchi O Jr (ed) River algae, 1st edn. Springer, Cham, pp 1-4

Necchi O Jr, Alves AHS (2005) Photosynthetic characteristics of the freshwater red alga Batrachospermum delicatulum (Skuja) Necchi \& Entwisle. Acta Bot Brasilica 19:125-137. https://doi.org/10.1590/S010233062005000100012

Necchi O Jr, Zucchi MR (2001) Photosynthetic performance of freshwater Rhodophyta in response to temperature, irradiance, $\mathrm{pH}$ and diurnal rhythm. Phycol Res 49:305-318. https://doi.org/10.1046/j.1440-1835.2001.00251.x

Pérez-Rodríguez E, Gómez I, Karsten U, Figueroa FL (1998) Effects of UV radiation on photosynthesis and excretion of UV-absorbing compounds of Dasycladus vermicularis (Dasycladales, Chlorophyta) from southern Spain. Phycologia 37:379-387. https://doi.org/10.2216/i0031-888437-5-379.1

Peschek F, Bischof K, Bilger W (2010) Screening of ultraviolet$A$ and ultraviolet-B radiation in marine green macroalgae (Chlorophyta). J Phycol 46:444-455. https://doi.org/10. 1111/j.1529-8817.2010.00825.x

Platt T, Gallegos CL, Harrison WG (1980) Photoinhibition of photosynthesis in natural assemblages of marine phytoplankton. J Mar Res 38:687-701

Rastogi RP, Sonani RR, Madamwar D (2014) The high-energy radiation protectant extracellular sheath pigment scytonemin and its reduced counterpart in the cyanobacterium. Bioresour Technol 171:396-400. https://doi.org/10.1016/j. biortech.2014.08.106

Ritchie RJ (2006) Consistent sets of spectrophotometric chlorophyll equations for acetone, methanol and ethanol solvents. Photosynth Res 89:27-41. https://doi.org/10. 1007/s11120-006-9065-9

Ritchie RJ (2008) Universal chorophyll equations for estimating chorophyll a, b, c and total chorophyll in natural assemblages of photosynthetic organims using acetone, methanol, or ethanol solvents. Photosynthetica 46:115-126

Roleda MY, Van De Poll WH, Hanelt D, Wiencke C (2004) PAR and UVBR effects on photosynthesis, viability, growth and DNA in different life stages of two coexisting Gigartinales: implications for recruitment and zonation 
pattern. Mar Ecol Prog Ser 281:37-50. https://doi.org/10. 3354/meps 281037

Roleda MY, Lütz-Meindl U, Wiencke C, Lütz C (2010) Physiological, biochemical, and ultrastructural responses of the green macroalga Urospora penicilliformis from Arctic Spitsbergen to UV radiation. Protoplasma 243:105-116. https://doi.org/10.1007/s00709-009-0037-8

Roleda MY, Nyberg CD, Wulff A (2012) UVR defense mechanisms in eurytopic and invasive Gracilaria vermiculophylla (Gracilariales, Rhodophyta). Physiol Plant 146:205-216. https://doi.org/10.1111/j.1399-3054.2012. 01615.x

Ryan KG, McMinn A, Mitchell KA, Trenerry L (2002) Mycosporine-like amino acids in Antarctic sea ice algae, and their response to UVB radiation. Zeitschr Naturforsch C 57:471-477

Sabater S, Artigas J, Corcoll N, Proia L, Timoner X, Tomés E (2016) Ecophysiology of river algae. In: Necchi O Jr (ed) River algae, 1st edn. Springer, Cham, pp 197-217

Schreiber U, Bilger W, Neubauer C (1994) Chlorophyll fluorescence as a non-intrusive indicator for rapid assessment of in vivo photosynthesis. In: Schulze ED, Caldwell MM (eds) Ecophysiology of photosynthesis. Springer, Berlin, pp 49-70

Schubert N, García-Mendoza E (2008) Photoinhibition in red algal species with different carotenoid profiles. J Phycol 44:1437-1446. https://doi.org/10.1111/j.1529-8817.2008. 00590.x
Sheath RG, Hambrook JA (1990) Freshwater ecology. In: Cole KM, Sheath RG (eds) Biology of the red algae. Cambridge University Press, Cambridge, pp 423-453

Simioni C, Schmidt ÉC, Felix MRDL, Polo LK, Rover T, Kreusch M, Pereira DT, Chow F, Ramlov F, Maraschin M, Bouzon ZL (2014) Effects of ultraviolet radiation (UVA + UVB) on young gametophytes of Gelidium floridanum: growth rate, photosynthetic pigments, carotenoids, photosynthetic performance, and ultrastructure. J Photochem Photobiol 90:1050-1060. https://doi.org/10. 1111/php. 12296

Sinha RP, Häder D-P (2002) Life under solar UV radiation in aquatic organisms. Adv Space Res 30:1547-1556. https:// doi.org/10.1016/S0273-1177(02)00370-8

Sinha RP, Klisch M, Groniger A, Häder DP (2000) Mycosporine-like amino acids in the marine red alga Gracilaria cornea: effects of UV and heat. Environ Exp Bot 43:33-43

Stevenson RJ (1996) An introduction to algal ecology in freshwater benthic habitats. In: Stevenson RJ, Bothwell ML, Lowe RL (eds) Algal ecology: freshwater benthic ecosystems. Academic Press, San Diego, pp 3-30

van Kooten O, Snell JJH (1990) The use of chlorophyll fluorescence nomenclature in plant stress physiology. Photosynth Res 25:147-150. https://doi.org/10.1007/ BF00033156

White AJ, Critchley C (1999) Rapid light curves: a new fluorescence method to assess the state of the photosynthetic apparatus. Photosynth Res 59:63-72. https://doi.org/10. 1023/A:1006188004189 